\title{
Universiteit
}

Leiden

The Netherlands

\section{Intimate Partner Homicide by Presence or Absence of a Self-Destructive Act}

Liem, M.C.A.; Roberts, D.

\section{Citation}

Liem, M. C. A., \& Roberts, D. (2009). Intimate Partner Homicide by Presence or Absence of a Self-Destructive Act. Homicide Studies, 13, 339-354. Retrieved from https://hdl.handle.net/1887/15573

Version: $\quad$ Not Applicable (or Unknown)

License: $\quad$ Leiden University Non-exclusive license

Downloaded from: $\quad$ https://hdl.handle.net/1887/15573

Note: To cite this publication please use the final published version (if applicable). 


\title{
Intimate Partner Homicide by Presence or Absence of a Self-Destructive Act
}

\section{Marieke Liem' and DarryIW. Roberts²}

\begin{abstract}
Intimate partner homicide is not only the most common type of domestic homicide, but is also most prevalent in homicides followed by a self-destructive act (e.g., suicide or a suicide attempt). To date, very few studies have addressed this unique circumstance of intimate partner homicide, particularly in comparison to intimate partner homicides that are not followed by a self-destructive act. One possible reason for this lack of research might be that many consider homicide and suicide discrete phenomena, therefore devaluing the similarities that might exist between them. The "Currents of Lethal Violence" analogy describes homicide and suicide as two currents in a stream of lethal violence. We propose that intimate partner homicide followed by a self-destructive act mixes these currents. This study aims to assess the differences among intimate partner homicide perpetrators who did and did not commit a self-destructive act following the homicide. Descriptive and bivariate analyses of predictive variables were obtained from the records of $34 \mathrm{I}$ male intimate partner homicide perpetrators held at a Dutch forensic observation hospital between 1980 and 2006, of which 44 committed a self-destructive act following the offense. Perpetrators that attempted suicide were more likely to have a diagnosis of depressive illness and to have threatened suicide prior to the offense. Perpetrators in this group showed evidence of far-reaching dependency on the victim and a fear of abandonment. Further research into this area is necessary to elucidate this issue.
\end{abstract}

\section{Keywords}

intimate partner homicide, spousal homicide, domestic violence, homicide-suicide, forensic psychology

\footnotetext{
'Utrecht University, Netherlands

${ }^{2}$ University of Maryland School of Nursing, Baltimore

\section{Corresponding Author:}

Marieke Liem, Utrecht University, Faculty of Law, Willem Pompe Institute for Criminal Law \& Criminology, Section Forensic Psychiatry and Psychology, Janskerkhof 16, 3512 BM Utrecht, Netherlands Email:m.liem@law.uu.nl
} 


\section{Introduction}

Intimate partner homicide (IPH) is the most common type of domestic homicide. Although both men and women commit IPH, men perpetrate three of every four incidences. IPH is the only form of lethal violence in which women are the principal victims (Koziol-McLain et al., 2006; Milroy, 1995; Starzomski \& Nussbaum, 2000). IPH also has the highest incidence of homicide-suicide of any type of homicide. In addition, IPH followed by a self-destructive act (SDA; for example, suicide or attempted suicide) is almost exclusively committed by men (Barber et al., 2008; Harper \& Voigt, 2007; Koziol-McLain et al., 2006; Malphurs \& Cohen, 2002; Marzuk, Tardiff, \& Hirsch, 1992; Milroy, 1995; Roberts, 2009; Starzomski \& Nussbaum, 2000). Men committing lethal SDAs leave little or nothing for scientists to learn about the antecedents of the event without resorting to secondary resources, such as psychological autopsy, for information (Cavanagh, Carson, Sharpe, \& Lawrie, 2003). The study at hand overcomes this limitation by using homicides followed by a failed suicide of the perpetrator (Berman, 1996; Brett, 2002) as the sources of information. This allows for the studying of psychiatric factors as well as the motives underlying the offence. It has been suggested that in homicides followed by a serious suicide attempt, the nonlethal outcome of the act may be a matter of chance (Hillbrand, 2001). Hence, this group is likely to have similar characteristics to the homicide-suicide group.

Since the 19th and into the 20th centuries, Sigmund Freud (1917(1961)), Morselli (1882), and Levi (1980) have proposed and scientifically supported the idea that suicide is homicide of the self. More recently, others (Batton, 1999; Batton \& Ogle, 2007; Unnithan, Huff-Corzine, Corzine, \& Whitt., 1994; Vollum \& Titterington, 2001; Wu, 2003) have added empirical support to that notion, although still others, such as Durkheim (1951) and Harries (1997), divorce these two forms of lethal violence. However, in cases of homicide-suicide, particularly IPH followed by suicide, it is difficult to separate the two occurrences. One logical way in which to consider these acts together is by using the "Currents of Lethal Violence" analogy as introduced by Whitt (1994).

The "Currents of Lethal Violence" analogy gives a unique perspective through which to comprehend this particular variety of intentional death (for a comprehensive description, please see Whitt, 1994). This analogy describes lethal violence as a stream consisting of two distinct currents, the homicide current and the suicide current. The width of each current represents the rate of each type of lethal violence. The combined currents comprise the overall rate of lethal violence. In this model, suicide and homicide are alternate and causal forms of death, constituting a function of two sets of mechanisms that produce frustration and then direct it inward or outward.

The forces that produce frustration are those social and cultural factors, such as level of industrialization, employment rate, natural disasters, and civil unrest, that in turn influence the total rate of lethal violence (e.g., sum of homicide rate and suicide rate). Once produced, other forces, such as cultural and structural factors, direct frustration in a manner that prompts perpetrators to direct their violent drives inward to suicide or outward to homicide. These cultural and structural factors include childrearing 
practices, effects of certain economic cycles (e.g., inflation and plant closings; Henry \& Short, 1967), degree of social isolation (Levi, 1980), region of nation or continent (Harries, 1997), and cultural acceptance of violence (West, 1965; Whitt, 1994). This analogy builds in part on the works of Merton, whose 1938 study of anomie concluded that homicide rates are highest in cultures that accept outwardly directed violence and believe that people's destinies are outside of their control, whereas suicide rates are highest in those cultures that do not accept outwardly directed violence and believe that people control their own destinies.

IPH followed by a SDA blurs the otherwise clear lines drawn by the analogy as proposed by Whitt (1994) and supported by others (He, Cao, Wells, \& Maguire, 2003; $\mathrm{Wu}, 2003)$. This model does not discuss the conditions under which homicide and suicide can occur as a single event. If homicide is outwardly directed and suicide is inwardly directed, how does someone commit homicide and then commit a SDA? This question requires some discussion of homicide and suicide separately and then some elucidation from studies focusing on their co-occurrence.

\section{Homicide}

In the United States, men account for the vast majority of both homicide perpetrators and homicide victims (Fox \& Zawitz, 2006). Homicides with female perpetrators and victims account for the smallest homicide category (Fox \& Zawitz, 2006; Glass, Koziol-McLain, Campbell, \& Block, 2004). Although these parameters represent findings from the United States, they are similar to those reported by Smit, Bijleveld, and Van Der Zee (2001) in the Netherlands. Homicide perpetrators are more likely than perpetrators of other crimes to have been arrested previously for crimes against persons (Wolfgang, 1967). Furthermore, they are reported to be of lower socioeconomic status and having less education (Fox \& Zawitz, 2006). In addition, although a large proportion of homicide perpetrators have no diagnosed mental illnesses, such illnesses are considerably more common in perpetrators of homicides than they are in perpetrators of other crimes or in the general population (Hiroeh, Appleby, Mortensen, \& Dunn, 2001; Schanda et al., 2004; Shaw et al., 2006), psychotic disorders as well as substance-related disorders being common (Auerhahn \& Parker, 1999; Hiroeh et al., 2001; Schanda et al., 2004; Shaw et al., 2006).

\section{Suicide}

Women attempt suicide at higher rates than men (Roy \& Janal, 2005); however, as men tend to choose more lethal means, they complete suicide at higher rates than women (National Center for Health Statistics, 2005). Many studies have found that income and wealth increase suicide risk (Unnithan et al., 1994; Wu, 2003), whereas others positively correlate unemployment and lower income with suicide risk (Lorant, Kunst, Huisman, Costa, \&Mackenbach, 2005). However, most agree that risk for suicide increases in those with educations beyond high school (Kung, Liu, \& Juon, 1998) and in those who live alone, are childless, or have lost someone close to them due to death 
or divorce (Kposowa, 2001). Expectedly, suicide risk increases in mental illness and substance abuse (Pirkola, Isometsa, Heikkinen, \& Lönnqvist, 2000), depressive and psychotic disorders being common findings in suicide victims (Joiner, Brown, \& Wingate, 2005). In sum, previous research has shown homicide perpetrators and suicide victims to constitute different populations, directing aggressive impulses either outward (the so-called homicide stream) or inward (the so-called suicide stream).

\section{Homicide-Suicide}

Stack (1997) attempted to apply the stream analogy to homicide-suicide in the study of Chicago homicides. He concluded that the principle source of frustration in homicidesuicide stems from the perpetrator's inability to live with or without the victim. $\mathrm{He}$ argued that the homicide act overcomes a sense of helplessness but that the ensuing guilt causes suicide. Therefore, Stack suggested viewing homicide-suicide as containing both inward and outward attribution styles. Others consider homicide-suicides to be primarily suicidal. In this light, the homicide victim is "taken along" in the perpetrator's suicide (Milroy, 1995; West, 1965). Similarly, these acts can be understood as primarily suicidal as the perpetrator kills a part of himself in the person of his intimate partner. Acceptance of this argument lends credence to the suggestion that IPH followed by a SDA is consistent with the Currents analogy favoring the suicide current.

Men and women commit IPH for different reasons. Men typically commit this crime out of a fear of losing control over the victim (e.g., following an actual or threatened divorce or abandonment; Daly \& Wilson, 1988). Other reasons for male-perpetrated IPH include male domination of victims through emotional dependency rather than through physical means (Dutton \& Yamini, 1995; Koenraadt, 1999; Palermo, 1994; Serran \& Firestone, 2004). Furthermore, several researchers found that verbal threats of physical harm are important warning signals for impending fatal events (Berman, 1979; Felson \& Messner, 2000; Straus, 1991). Men who experience fantasies of homicide, make suicide threats, have diagnosed or undiagnosed depression, or have a history of intimate partner violence (IPV) are at increased risk for perpetrating IPH (Belfrage \& Rying, 2004; Berman, 1979; Straus, 1991). Alternatively, women commit acts of lethal violence to escape protracted physical abuse or to protect their children (Wilson \& Daly, 1992). Unlike men, women seem to choose between homicide and suicide, rather than a combination thereof, as their method of escape (Campbell, 1995; Stark \& Flitchcraft, 1995).

Studies comparing IPH to IPH followed by a SDA find that employment, education (Gillespie, Hearn, \& Silverman, 1998), older age, White race, cohabitation with the victim, and access to a firearm (Barber et al., 2008; Easteal, 1993; Lund \& Smorodinsky, 2001) are associated with a higher likelihood of suicide following IPH. Others found that at the time of the homicide, suicidal perpetrators were more likely to be under the influence of drugs and diagnosed with major depression (Bourget, Gagne, \& Moamai, 2000). Perpetrators are also more likely to show signs of premeditation but less likely to have a history of violent offenses (Dawson, 2005). 
Due to the nature of homicide-suicide events, all parties directly involved are dead, leaving little, if any, clinical documentation (Nock \& Marzuk, 1999). Consequently, several researchers have called for the study of survivors of these acts (Berman, 1979; Brett, 2002). The current study will rely on the analysis of IPHs involving a nonfatal SDA rather than a completed SDA. In addition, given the fact that IPH followed by a SDA are almost exclusively committed by men, and to improve the validity and strength of the findings, this study only focuses on male-perpetrated IPH.

Following the results from previous studies on this topic, the aim of the current study is to answer the following research questions:

Research Question 1: To what extent do men committing a SDA following an IPH differ from men not committing a SDA?

Research Question 2: To what extent do men committing IPH followed by a SDA suggest behaviors indicative of simple IPH?

The differences between the groups under study were examined using variables that were found indicative for either type of homicide by previous research.

\section{Method}

This study is based on the examination of clinical records in a forensic psychiatric hospital in the Netherlands, the Pieter Baan Centre. The centre has a national function. People accused of having committed serious crimes and whose criminal acts are thought to be related to a mental disorder or illness are incarcerated in the Centre for a period of 7 weeks. In this period, perpetrators undergo court-ordered pretrial multidisciplinary assessments to determine their degree of accountability at the time of the offense. The assessment consists of an investigation of the accused person's social environment by a social worker through interviews with family members, friends, and (former) colleagues; a report of the behavior on the ward by staff members; a medical examination; and a complete psychological and psychiatric assessment (Koenraadt, 1992; Koenraadt, Mooij, \& Mulbregt, 2007).

Data were collected from the Pieter Baan Centre archive for the period 1980-2006, during which time the centre evaluated 341 men accused of attempted or completed IPH. Although there is a clear judicial division between fatal and nonfatal homicides, from a forensic mental health perspective those accused of a fatal crime resemble those accused of an attempted fatal crime (Koenraadt, 1996; Liem \& Koenraadt, 2008). Assuming that the lethality of the act was beyond the influence of the perpetrator, attempted homicides have been included as well. The sample was divided into two groups based on the presence or absence of a SDA following the offense, giving a sample of 44 men and 297 men, respectively. It has to be emphasized that the individuals included in the study were unconvicted at the time their data were recorded. Later examination of court files confirmed that all were subsequently convicted. 
With regard to the representativeness of the study sample in relation to national data, we compared the relative occurrence of IPH in our sample to the national occurrence. In the period 1992-2001, ${ }^{1}$ a total of 30 IPHs ended in the suicide of the perpetrator. From Table 1 below, it can be deducted that in the period 1992-2001, approximately $20 \%$ of the total number of IPHs in the Netherlands were included in the sample.

\section{Terminology}

IPH is defined as the killing of an intimate partner, entailing spouses, ex-spouses, persons in current or former de facto relationships, or partners of same-sex relationships (Carcach \& James, 1998). A SDA is defined as an intentionally suicidal act. These SDAs cannot be equated with succeeded suicides: Those attempting suicide and those committing suicide constitute different populations (Mann, 2002). Hence, to exclude nonserious SDAs following an IPH, near-lethal SDAs are selected for the analysis. Cases in the current study are classified as involving a SDA if suicidal intent was present and if self-inflicted injuries were moderate to severe. Here, factors that were not under the control of the perpetrator played a prominent role in determining whether the victim(s) and perpetrator survived. These include the unexpected presence of witnesses who summon help, the promptness and quality of emergency medical response, weapon "failure," and so on (Hillbrand, 2001). Suicide pacts are a seemingly mutual arrangement between intimate partners resolving to die at the same time and, nearly always, at the same place (Cohen, 1961). These are included if the victim did not explicitly consent to the killing. Familicides are defined as the killing of an intimate partner and one or more children. Symbiosis originally refers to a commensal, or mutually dependent, living arrangement among certain species (De Bary, 1879, cf. Meloy, 1992). Here, the term applies to far-reaching interdependency between two intimate partners. In such a situation, from the individual's point of view, there is hardly a distinction between the self and the other. The presence of such extreme dependency in the victim-perpetrator relationship was determined in the psychological and psychiatric assessment of the perpetrator. Narcissistic rage refers to a reaction to a feeling of being hurt and/or being wronged in the context of pathological self-love. Narcissism is a psychological condition characterized by self-preoccupation, lack of empathy, and unconscious deficits in self-esteem. The feeling of being hurt makes the individual feel completely powerless, leading to a rage response (Kohut, 1971). The presence of narcissistic rage was established in the psychological and psychiatric assessment of the perpetrator.

\section{Statistical Analyses}

Due to sample and cell sizes, we restricted analyses to bivariate correlations using Pearson's chi-square tests and one-way ANOVAs between the two groups under study using an alpha probability set at .05 . 
Table I. Study Sample in Relation to Intimate Partner Homicide in the Netherlands, |992-200|

Number of intimate partner homicides

$\begin{array}{lc}\text { National occurrence } & 474 \\ \text { Perpetrator died of suicide } & 30 \\ \text { Perpetrator in Pieter Baan Centre } & \\ N & 89 \\ \% \text { of national occurrence } & 19 \% \\ \% \text { excluding suicide } & 20 \%\end{array}$

\section{Results}

These results are based on the comparison of 44 persons who committed a SDA following the offense with 297 who did not (see Table 2).

\section{IPH by Presence of Absence of a SDA}

Although no significant differences were observed with regard to age and education, it was found that suicidal men were significantly more likely to be unemployed (58\% vs. $\left.43 \% ; \chi^{2}=3.46, d f=1, p=.045\right)$ compared to their nonsuicidal counterparts.

With regard to contextual characteristics such as killing multiple victims, including killing in a so-called familicide, the suicidal group resembled the nonsuicidal group of perpetrators. Concerning the modus operandi, those committing a SDA following the offense were more likely to employ strangulation over other methods (41\% vs. $22 \%$; $\left.\chi^{2}=7.30, d f=1, p=.008\right)$. Overall, suicidal men killed their partners out of different motives than nonsuicidal men in being more likely to kill out of a narcissistic rage $\left(44 \%\right.$ vs. $\left.27 \% ; \chi^{2}=4.81, d f=1, p=.020\right)$. From a psychological point of view, narcissism, or love of the self, aims to protect one's self-esteem. When self-esteem is lowered or threatened by rejection or divorce, aggression arises as an instrument of recovery. From this point of view, the victim is killed to restore the perpetrator's sense of self. Here, aggression is externalized onto the victim rather than internalized toward the self. The results further indicated that suicidal perpetrators were more likely to have a symbiotic relationship with the victim $\left(34 \%\right.$ vs. $\left.7 \% ; \chi^{2}=28.07, d f=1, p=.000\right)$ compared to nonsuicidal perpetrators. No differences between the two groups were observed with regard to the situational characteristics: In both groups, approximately one fourth of the perpetrators were previously convicted of a violent offense. Previous IPV was common in both groups.

The two groups did not differ to a great extent with regard to psychopathological characteristics: In both groups, approximately one fifth was previously hospitalized, suffered from a psychotic disorder, and/or a substance abuse disorder. Those committing a SDA were, however, significantly more likely to be diagnosed with a depressive disorder $\left(23 \%\right.$ vs. $\left.6 \% ; \chi^{2}=15.37, d f=1, p=.001\right)$. 
Table 2. Intimate Partner Homicide by Presence or Absence of a SDA

\begin{tabular}{|c|c|c|c|}
\hline & $\operatorname{SDA}(n=44)$ & No SDA $(n=297)$ & Probability \\
\hline \multicolumn{4}{|l|}{ Socio-demographic characteristics } \\
\hline Age & $38.8( \pm 13.4)$ & $36.5( \pm 10.5)$ & .190 \\
\hline Unemployed & $25 / 43(58 \%)$ & $123 / 286$ (43\%) & $.045^{*}$ \\
\hline Low or no education & $18 / 42$ (43\%) & $84 / 285(30 \%)$ & .061 \\
\hline Dutch ethnicity & $30 / 44(68 \%)$ & I64/297 (55\%) & .071 \\
\hline \multicolumn{4}{|l|}{ Contextual characteristics } \\
\hline Familicide & $4 / 44(9 \%)$ & 13/297 (4\%) & .163 \\
\hline Multiple victims & $7 / 44(16 \%)$ & $31 / 297(10 \%)$ & .201 \\
\hline Modus operandus & & & - \\
\hline Firearm & $6 / 44(14 \%)$ & $44 / 294(15 \%)$ & \\
\hline Pointed weapon & $14 / 44$ (32\%) & $106 / 294(36 \%)$ & \\
\hline Striking weapon & $5 / 44(11 \%)$ & $32 / 294$ (1 I\%) & \\
\hline Strangulation & I8/44 (4I\%) & $65 / 294(22 \%)$ & \\
\hline Physical maltreatment & $0 / 44(0 \%)$ & $26 / 294(9 \%)$ & \\
\hline Other & I/44 (2\%) & $21 / 294(7 \%)$ & \\
\hline \multicolumn{4}{|l|}{ Motive } \\
\hline Psychotic & $8 / 44(18 \%)$ & $38 / 297(13 \%)$ & .224 \\
\hline Fear of abandonment & $16 / 44(36 \%)$ & $73 / 297(25 \%)$ & .073 \\
\hline Narcissistic rage & $12 / 44(27 \%)$ & I32/297 (44\%) & $.020 *$ \\
\hline Symbiosis & $15 / 44$ (34\%) & $22 / 296(7 \%)$ & $.000 *$ \\
\hline \multicolumn{4}{|l|}{ Situational characteristics } \\
\hline Criminal antecedents & I I/44 (25\%) & $86 / 294$ (29\%) & .350 \\
\hline Intimate partner violence & $16 / 42$ (38\%) & $147 / 285$ (52\%) & .071 \\
\hline Child abuse & $5 / 42(12 \%)$ & $35 / 285$ (13\%) & .565 \\
\hline \multicolumn{4}{|l|}{ Individual characteristics } \\
\hline Psychiatric hospitalization & $|0 / 4|(24 \%)$ & $44 / 265$ (I7\%) & .159 \\
\hline Depressive disorder & $10 / 43(23 \%)$ & $17 / 292(6 \%)$ & $.001 *$ \\
\hline Psychotic disorder & $9 / 44(20 \%)$ & $50 / 293(17 \%)$ & .356 \\
\hline $\begin{array}{l}\text { Psychoactive substance abuse } \\
\text { or dependence }\end{array}$ & $9 / 43(21 \%)$ & $50 / 292(17 \%)$ & .335 \\
\hline \multicolumn{4}{|l|}{ Indices of behavioral warning signs } \\
\hline Suicidal threats & $9 / 41(22 \%)$ & $21 / 261$ (8\%) & $.011 *$ \\
\hline Death threats against children & $0 / 41(0 \%)$ & $2 / 261$ (1\%) & - \\
\hline Homicidal thoughts against spouse & $2 / 4 I(5 \%)$ & $8 / 260(3 \%)$ & - \\
\hline Death threats against spouse & $4 / 4 \mid(10 \%)$ & $38 / 261$ (15\%) & .290 \\
\hline Premeditation & $24 / 42$ (57\%) & $|22 / 22|(55 \%)$ & .477 \\
\hline
\end{tabular}

Note: SDA = self-destructive act. An "- " is noted for those cross-tabulations in which the numbers per cell were too small to conduct statistical analyses. $* p<.05$.

The results further showed that suicidal perpetrators were more likely to threaten suicide prior to the offense $\left(22 \%\right.$ vs. $\left.8 \% ; \chi^{2}=7.66, d f=1, p=.011\right)$. In some cases, the perpetrator actually attempted suicide immediately preceding the offense. Relationship problems within the intimate couple were usually cited as reasons for such 
attempts. When the victim tried to interfere in a suicide attempt, aggression turned outward onto the victim. In addition, a considerable number of cases in which the perpetrator threatened or planned suicide were not actually followed by a SDA. In such cases, it was likely that the suicide was planned to take place in the presence of the victim to punish her for causing him harm. Yet, in these cases, when facing the victim, inward aggression turned outward to such an extent that the perpetrator did not attempt to commit a SDA after the homicide: arguably, part of the self was already killed with the victim.

Finally, in 21 SDA cases, the SDA following the homicide was premeditated. When the victim fatally interfered, the perpetrator either staged the event as a suicide pact or alternatively planned that both the victim and he should die. In 18 SDA cases, the SDA was not premeditated. Here, the SDA resulted from the perpetrator's feelings of guilt related to the homicide, desperation after discovering what he had done, or fear of judicial consequences. In 7 cases, the role of suicide premeditation could not be established.

\section{Discussion}

The present study has examined 341 perpetrators of IPH, 44 of whom committed a SDA following the homicide. Although the two groups largely resemble one another, differences were found with regard to employment, modus operandi, the motive for the offense, depressive disorder as well as suicide threats preceding the event. When comparing men accused of "simple" IPH to men accused of IPH followed by a SDA, it was found that the latter were more likely to be unemployed. This is consistent with findings from studies by Campbell and Sharps (Campbell et al., 2003; Sharps, Campbell, Campbell, Gary, \& Webster, 2003; Sharps et al., 2001) of risk factors for IPH, but it stands in contrast to Gillespie et al.'s (1998) findings, which emphasized that bonds to society, such as employment, increase the likelihood that the homicide perpetrator would commit suicide following a homicide. Testing the "Currents of Lethal Violence" analogy on national data, $\mathrm{Wu}$ (2003) found that unemployment rate correlated directly with homicide rate but opposite to suicide rate. In the current sample, we found that suicidal perpetrators were more likely to be unemployed than nonsuicidal perpetrators. We tentatively suggest that the reasons for suicide following a homicide could lie in the very fact that uneducated, unemployed men suffer from a high degree of deprivation and frustration. From this point of view, they had "nothing more to lose" after having killed their intimate partner, thereby decreasing the suicide threshold. On the other hand, the unemployed and uneducated man could have directed the frustration from his dismal situation inward. According to this line of reasoning, these IPHs followed by a SDA arise out of a type of frustration not related to his marital relationship. This is consistent with the streams analogy, which suggests that this type of frustration directs lethal violence toward suicide.

Nonsuicidal individuals were more likely to kill their intimate partners as a result of narcissistic injury, whereas suicidal individuals were typically motivated by a fear 
of abandonment. This reflects the role of dependency in IPHs followed by a SDAsometimes evolving to such an extent that the relationship with the victim was symbiotic in nature. Arguably, when the victim threatens to end the relationship, a part of the perpetrator's sense of identity is lost-through the symbiotic nature of their relationship, the victim has become a part of the perpetrator. When emotional dependency is not enough to convince the victim to stay, he kills her. When killing the victim, a part of the self is killed with it (Palermo, 1994). When joining the victim in death by committing suicide, he retains the relationship that could not be maintained in life. Such a fear of abandonment is also reflected in the frequent use of so-called "hands-on" methods, such as strangulation, in IPHs followed by SDAs compared to "simple" IPHs.

Furthermore, it was found that IPV was common in both groups - a finding reported by others cross-culturally (Lindqvist \& Gustafsson, 1995; Malphurs \& Cohen, 2002; Morton, Runyan, Moracco, \& Butts, 1998; Palermo, 1994; Stack, 1997). Here, physical abuse is typically committed by a possessive male and arises out of suspected infidelity. He kills his partner so that no one can have her but him; by subsequently committing suicide, he aims to continue their bond in death.

Consistent with findings from other studies (Bourget et al., 2000), those committing a SDA were more likely to have a depressive disorder. The link between depression and suicidal behavior has been well established (Joiner et al., 2005). Perceiving depressive disorders as symptomatic of suicide rather than homicide supports the notion that IPHs followed by SDAs are an expression of suicidal rather than an expression of homicidal behavior. From a psychodynamic perspective, Klein (1935/1975) had previously argued that a fear of losing a loved object (i.e., an [estranged] intimate partner) precipitates depression. An overrepresentation of mood disorders among the SDA group, then, could be explained by the perpetrator's fear of abandonment and subsequent loss of self-esteem. In the case of spousal abandonment, his self is shattered, to which he responds with violence toward the cause of his dejection.

Finally, we found that persons committing a SDA following IPH were more likely to have expressed suicidal threats shortly before the offense - a finding consistent with other studies (Belfrage \& Rying, 2004; Koziol-McLain et al., 2006). A previously suicidal perpetrator might kill the object of frustration and aggression, thus killing the part of the self that is associated with frustration and aggression. Although such a perpetrator initially aimed to apply (lethal) violence against himself, killing his (estranged) spouse serves a similar purpose, making self-destruction unnecessary. Arguably, by killing his (estranged) partner as part of him, suicide is, in a way, already accomplished.

The current data on IPHs show that the choice between homicide and suicide is typically an ambivalent one. Although a SDA can be committed out of guilt over the homicide, in a large proportion of cases, suicidal ideation was either displaced onto the victim or the victim was to such an extent integrated in the individual's perception of self that the perpetrator could not be separated from her. The prevalence of unemployment, depressive disorder, and previous suicide threats and suicide plans among those committing a SDA following the killing of an intimate partner suggest that these 
individuals have more in common with suicide victims than with homicide perpetrators. According to the stream analogy, this subgroup of IPHs followed by a SDA seems to resemble the suicide current over the homicide current: In killing his intimate partner, the perpetrator kills a part of the self.

Based on present findings, preventive measures in the area of IPH and IPH followed by suicide should focus on the presence of intimate partner violence as well as signs of premeditation, including previous suicide threats. Estranged intimate partners carry additional risk when the terminated relationship was dependent or symbiotic in nature.

\section{Limitations}

The current study relied on data from a forensic observation hospital. The inclusion of only living perpetrators might have caused an overrepresentation of nonsuicidal perpetrators, as many of those committing a SDA are likely not to have survived. This selection bias could also explain the differences in outcomes between other studies on this topic and this study. It is of importance to mention that attempted homicides were also included in this sample. In addition, of all survivors of such acts, those sent to a forensic hospital are already thought to deviate psychologically from other accused persons (Haapasalo \& Petäjä, 1999; Marleau, Poulin, Webanck, Roy, \& Laporte 1999). Finally, differential judicial coding might have caused some suicide pact survivors to be excluded from the present analysis.

To obtain a more complete and accurate sample, future research should aim to incorporate survivors who were not sent to the hospital as well as those who did not survive. Coroner's reports would provide for a reliable basis but have the limitation of providing few details on the underlying characteristics of the offense. Incorporating multiple data sources in a so-called between-method (Bryman, 2004) will ensure that any bias in a particular data set is neutralized when combined with other data sources.

One of the main strengths of this study is that it compares IPH followed by a SDA with IPH not followed by a SDA. Previous studies on this specific topic have been conducted in the United States and Canada (Cooper \& Eaves, 1996; Dawson, 2005; Lund \& Smorodinsky, 2001). Many of their findings have been replicated, suggesting that several aspects of this phenomenon are generic throughout the Western world. These aspects include a male propriety mindset, mental illness, and premeditation of the crime. The differences between the present study and earlier studies could give new insights into the understanding of IPH-suicide.

\section{Conclusion}

The current results suggest significant differences between those who did and did not commit a SDA following an IPH. The majority of the findings correspond to findings reported elsewhere. Regarding demographic and situational characteristics, the differences between the two groups are not distinctively marked. In spite of the similarities 
between the groups, from the current data a clear subgroup arises that can be characterized as men who exhibit depressive symptoms through suicide threats preceding the offense. They typically commit the offense out of a fear of abandonment by the victim on whom they feel (symbiotically) dependent. Further studies on noninstitutionalized populations in the Netherlands and elsewhere would help to elucidate the antecedents of this crime.

\section{Declaration of Conflict of Interest}

The authors declared no potential conflicts of interests with respect to the authorship and/or publication of this article.

\section{Funding}

The authors declared no financial support for the research and/or authorship of this article.

\section{Note}

1. Specific national statistics on domestic homicide only became available in the Netherlands since 1992 (Nieuwbeerta \& Leistra, 2007). Before then, no uniform national homicide database availability was recorded for specific types of homicide.

\section{References}

Auerhahn, K., \& Parker, R. N. (1999). Drugs, alcohol, and homicide. In M. D. Smith \& M. A. Zahn (Eds.), Studying and preventing homicide: Issues and challenges (pp. 97-114). Thousand Oaks, CA: SAGE.

Barber, C. W., Azrael, D., Hemenway, D., Olson, L. M., Nie, C., Schaechter, J., et al. (2008). Suicides and suicide attempts following homicide. Homicide Studies, 12, 285-297.

Batton, C. (1999). The stream analogy: An historical study of lethal violence rates from the perspective of the integrated homicide-suicide model. Nashville, TN: Vanderbilt University.

Batton, C., \& Ogle, R. S. (2007). Who's it gonna be-you or me? The potential of social learning for integrated homicide-suicide theory. In R. L. Akers \& G. F. Jensen (Eds.), Social learning theory and the explanation of crime (pp. 85-108). New Brunswick, NJ: Transaction.

Belfrage, H., \& Rying, M. (2004). Characteristics of spousal perpetrators: A study of all cases of spousal homicide in Sweden 1990-1999. Criminal Behaviour and Mental Health, 14, 121-133.

Berman, A. L. (1979). Dyadic death: Homicide-suicide. Suicide and Life-Threatening Behavior, 9. $15-23$

Berman, A. L. (1996). Dyadic death: A typology. Suicide and Life Threatening Behavior, 26, $342-350$

Bourget, D., Gagne, P., \& Moamai, J. (2000). Spousal homicide and suicide in Quebec. Journal of the American Academy of Psychiatry and Law, 28, 179-182.

Brett, A. (2002). Murder-parasuicide: A case series in western Australia. Psychiatry, Psychology and Law, 9, 96-99.

Bryman, A. (2004). Social research methods (2nd ed.). Oxford, UK: Oxford University Press.

Campbell, J. C. (1995). Prediction of homicide of and by battered women. In J. C. Campbell (Ed.), Assessing dangerousness: Violence by sexual offenders, batterers and child abusers (pp. 96-113). London: SAGE. 
Campbell, J. C., Webster, D., Koziol-McLain, J., Block, C., Campbell, D., Curry, M. A., et al. (2003). Risk factors for femicide in abusive relationships: Results from a multisite case control study. American Journal of Public Health, 93, 1089-1097.

Carcach, C., \& James, M. (1998). Homicide between intimate partners in Australia (Trends \& Issues in Crime and Criminal Justice, No. 90). Canberra: Australian Institute of Criminology.

Cavanagh, J. T. O., Carson, A. J., Sharpe, M., \& Lawrie,. S. M. (2003). Psychological autopsy studies of suicide: A systematic review. Psychological Medicine, 33, 395-405.

Cohen, J. (1961). A study of suicide pacts. Medico-Legal Journal, 29, 144-151.

Cooper, M., \& Eaves, D. (1996). Suicide following homicide in the Family. Violence and Victims, 11, 99-112.

Daly, M., \& Wilson, M. (1988). Homicide. New York: Aldine de Gruyter.

Dawson, M. (2005). Intimate femicide followed by suicide: Examining the role of premeditation. Suicide and Life-Threatening Behavior, 35, 76-90.

Durkheim, E. (1951). Suicide. New York: Free Press.

Dutton, D. G., \& Yamini, S. (1995). Adolescent parricide: An integration of social cognitive theory and clinical views of projective-introjective cycling. American Journal of Orthopsychiatry, 65, 1367-1386.

Easteal, P. W. (1993). Killing the beloved. Canberra: Australian Institute of Criminology.

Felson, R. B., \& Messner, S. F. (2000). The control motive in intimate partner violence. Social Psychology Quarterly, 63, 86-94.

Fox, J. A., \& Zawitz, M. W. (2006). Homicide trends in the United States. Washington, DC: Government Printing Office.

Freud, S. (1917 (1961)). Mourning and melancholia. In: Strachey, J. (Ed.), The standard edition of the complete psychological works of Sigmund Freud: Vol. 14 (pp. 243-258). London: HogarthPress.

Gillespie, M., Hearn, V., \& Silverman, R. A. (1998). Suicide following homicide in Canada. Homicide Studies, 2, 46-63.

Glass, N., Koziol-McLain, J., Campbell, J. C., \& Block, C. R. (2004). Female-perpetrated femicide and attempted femicide: A case study. Violence Against Women, 10, 606-625.

Haapasalo, J., \& Petäjä, S. (1999). Mothers who killed or attempted to kill their child: Life circumstances, childhood abuse and types of killing. Violence and Victims, 14, 219-239.

Harper, D. W., \& Voigt, L. (2007). Homicide followed by suicide: An integrated theoretical perspective. Homicide Studies, 11, 295-318.

Harries, K. D. (1997). Serious violence: Patterns of homicide and assault in America. Springfield, IL: Thomas.

He, N., Cao, L., Wells, W., \& Maguire, E. R. (2003). Forces of production and direction: A test of an expanded model of suicide and homicide. Homicide Studies, 7, 36-57.

Henry, A., \& Short, J. (1967). Status and relational systems. In M. E. Wolfgang (Ed.), Studies in homicide (pp. 255-270). New York: Harper \& Row.

Hillbrand, M. (2001). Homicide-suicide and other forms of co-occurring aggression against self and against others. Professional Psychology: Research and Practice, 32, 626-635.

Hiroeh, U., Appleby, L., Mortensen, P. B., \& Dunn, G. (2001). Death by homicide, suicide, and other unnatural causes in people with mental illness: A population-based study. Lancet, 358, 2110-2112. 
Joiner, T. E., Brown, J. S., \& Wingate, L. R. (2005). The psychology and neurobiology of suicidal behavior. Annual Review of Psychology, 56, 287-314.

Klein, M. (1975). A contribution to the psychogenesis of manic-depressive states. In The writings of Melanie Klein (Vol. 1, pp. 262-289). London: Hogarth Press. (Original work published 1935).

Koenraadt, F. (1992). The individualizing function of forensic multidisciplinary assessment in a Dutch residential setting: The Pieter Baan experience. International Journal of Law and Psychiatry, 15, 195-203.

Koenraadt, F. (1996). Parricide: An ultimate offense. Deventer, Netherlands: Gouda Quint.

Koenraadt, F. (1999). Male perpetrators of domestic homicide: A reflection on dependency in men killing their child or partner. In F. Bakker, F. Koenraadt, \& A. Mooij (Eds.), Om ernstige zaken (pp. 47-56). Gouda, Netherlands: Quint.

Koenraadt, F., Mooij, A., \& Mulbregt, J. (2007). The mental condition in criminal law: Forensic mental health assessment in a residential setting. Amsterdam: Dutch University Press.

Kohut, H. (1971). The analysis of the self: A systematic approach to the psychoanalytic treatment of narcissistic personality disorders. New York: International Universities Press.

Koziol-McLain, J., Webster, D., McFarlane, J., Block, C. R., Ulrich, Y., Glass, N., et al. (2006). Risk factors for femicide-suicide in abusive relationships: Results from a multisite study. Violence and Victims, 21, 3-21.

Kposowa, A. J. (2001). Unemployment and suicide: A cohort analysis of social factors predicting suicide in the U.S. National longitudinal mortality study. Psychological Medicine, 31, 127-138.

Kung, H. C., Liu, X., \& Juon, H. S. (1998). Risk factors for suicide in Caucasians and in African Americans: A matched case-control study. Social Psychiatry and Psychiatric Epidemiology, $33,155-161$.

Levi, K. (1980). Homicide as conflict resolution. Deviant Behavior, 1, 281-307.

Liem, M., \& Koenraadt, F. (2008). Filicide: A comparative study of maternal versus paternal child homicide. Criminal Behaviour and Mental Health, 18, 166-176.

Lindqvist, P., \& Gustafsson, L. (1995). Homicide followed by the offenders suicide in northern Sweden. Nordic Journal of Psychiatry, 49, 17-24.

Lorant, V., Kunst, A. E., Huisman, M., Costa, G., \& Mackenbach, J. (2005). Socio-economic inequalities in suicide: A European comparative study. British Journal of Psychiatry, 187, 49-54.

Lund, L. E., \& Smorodinsky, S. (2001). Violent death among intimate partners: A comparison of homicide and homicide followed by suicide in California. Suicide and Life Threatening Behavior, 31, 451-459.

Malphurs, J. E., \& Cohen, D. (2002). A newspaper surveillance study of homicide-suicide in the United States. American Journal of Forensic Medicine and Pathology, 23, 142-148.

Mann, J. J. (2002). A current perspective of suicide and attempted suicide. Annals of Internal Medicine, 136, 302-311.

Marleau, J. D., Poulin, B., Webanck, T., Roy, R., \& Laporte, L. (1999). Paternal filicide: A study of 10 men. Canadian Journal of Psychiatry, 44, 57-63.

Marzuk, P. M., Tardiff, K., \& Hirsch, C. S. (1992). The epidemiology of murder-suicide. Journal of the American Medical Association, 267, 3179-3183. 
Meloy, J. R. (1992). Violent attachments. London: Jason Aronson.

Merton, R. K. (1938). Social structure and anomie. American Sociological Review, 3, 672-682.

Milroy, C. M. (1995). The epidemiology of homicide-suicide (dyadic death). Forensic Science International, 71, 117-122.

Morselli, E. A. (1882). Suicide: An essay on comparative moral statistics. New York: D. Appleton $\&$ Co.

Morton, E., Runyan, C. W., Moracco, K. E., \& Butts, J. (1998). Partner homicide-suicide involving female homicide victims: A population-based study in North Carolina, 1988-1992. Violence and Victims, 13, 91-106.

National Center for Health Statistics. (2005). Health, United States, 2005: With chartbook on trends in the health of Americans (Rep. No. Library of Congress Catalog Number 76-641496). Hyattsville, MD: National Center for Health Statistics.

Nieuwbeerta, P., \& Leistra, G. (2007). Lethal violence: Homicide in the Netherlands 1992-2006. Amsterdam: Prometheus.

Nock, M. K., \& Marzuk, P. M. (1999). Murder-suicide. In D. G. Jacobs (Ed.), The Harvard medical school guide to suicide assessment and intervention (pp. 188-209). San Francisco: Jossey-Bass.

Palermo, G. B. (1994). Murder-suicide: An extended suicide. International Journal of Offender Therapy and Comparative Criminology, 10, 106-118.

Pirkola, S. P., Isometsa, E. T., Heikkinen, M. E., \& Lönnqvist, J. K. (2000). Suicides of alcohol misusers and non-misusers in a nationwide population. Alcohol and Alcoholism, $35,70-75$.

Roberts, D.W. (2009) Intimate partner homicide: Using a 20-year national panel to identify patterns and prevalence. Ph.D. dissertation, University of Maryland, Baltimore. Reference is listed as DAI-A 70/06, Dec 2009.

Roy, A., \& Janal, M. (2005). Family history of suicide, female sex, and childhood trauma: Separate or interacting risk factors for attempts at suicide? Acta Psychiatrica Scandinavica, 112, 367-371.

Schanda, H., Knecht, G., Schreinzer, D., Stompe, T., Ortwein-Swoboda, G., \& Waldhoer, T. (2004). Homicide and major mental disorders: A 25-year study. Acta Psychiatrica Scandinavica, 110, 98-107.

Serran, G., \& Firestone, P. (2004). Intimate partner homicide: A review of the male proprietariness and the self-defense theories. Aggression and Violent Behavior, 9, 1-15.

Sharps, P. W., Campbell, J., Campbell, D., Gary, F., \& Webster, D. (2003). Risky mix: Drinking, drug use, and homicide (Rep. No. 196546). Washington, DC: National Institute of Justice.

Sharps, P. W., Koziol-McLain, J., Campbell, J., McFarlane, J., Sachs, C., \& Xu, X. (2001). Health care providers' missed opportunities for preventing femicide. Preventive Medicine: An International Journal Devoted to Practice and Theory, 33, 373-380.

Shaw, J., Hunt, I. M., Flynn, S., Meehan, J., Robinson, J., Bickley, H., et al. (2006). Rates of mental disorder in people convicted of homicide: National clinical survey. British Journal of Psychiatry, 188, 143-147.

Smit, P., Bijleveld, C., \& Van Der Zee, S. (2001). Homicide in the Netherlands: An exploratory study of the 1998 Cases. Homicide Studies, 5, 293-310. 
Stack, S. (1997). Homicide followed by suicide: An analysis of Chicago data. Criminology, 35, 435-454.

Stark, E., \& Flitchcraft, A. (1995). Killing the beast within: Woman battering and female suicidality. International Journal of Health Services, 25, 43-64.

Starzomski, A., \& Nussbaum, D. (2000). The self and the psychology of domestic homicidesuicide. International Journal of Offender Therapy and Comparative Criminology, 44, 468-479.

Straus, M. A. (1991). New theory and old canards about family violence research. Social Problems, 38, 180-197.

Unnithan, N. P., Huff-Corzine, L., Corzine, J., \& Whitt, H. P. (1994). The currents of lethal violence: An integrated model of suicide and homicide. Albany: State University of New York Press.

Vollum, S., \& Titterington, V. B. (2001). Gender, attributional styles, and direction of lethal violence. Homicide Studies, 5, 227-252.

West, D. J. (1965). Murder followed by suicide. Cambridge, MA: Harvard University Press.

Whitt, H. P. (1994). The integrated model. In N. P. Unnithan, L. Huff-Corzine, J. Corzine, \& H. P. Whitt (Eds.), The currents of lethal violence: An integrated model of suicide and homicide (pp. 95-116). Albany: State University of New York Press.

Wilson, M., \& Daly, M. (1992). Whom kills whom in spouse killings? On the exceptional sex ratio of spousal homicides in the United States. Criminology, 30, 189-215.

Wolfgang, M. E. (1967). Criminal homicide and the subculture of violence. In M. E. Wolfgang (Ed.), Studies in homicide (pp. 3-14). New York: Harper \& Row.

$\mathrm{Wu}, \mathrm{B} .(2003)$. Testing the stream analogy for lethal violence: A macro study of suicide and homicide. Western Criminology Review, 4, 215-225.

\section{Bios}

Marieke Liem, MSc, MPhil is a researcher in forensic psychology and psychiatry at Utrecht University, Netherlands. Her research focuses on various forms of domestic homicide, in particular on homicides followed by suicides that take place within the family. Her current research interests involve intimate partner homicide, child homicide, homicide-suicide as well as the media reporting on these events.

Darryl W. Roberts, $\mathrm{PhD}, \mathrm{MS}, \mathrm{RN}$, has been an assistant professor at the University of Maryland School of Nursing since 2002. His research focuses on lethal violence from the perspectives of mental health public policy and public health informatics. He has authored or coauthored papers on intimate partner homicide, suicide, and other topics. 